\title{
Differences in Plant Species Composition as Evidence of Alternate States in the Sagebrush Steppe
}

\author{
Emily Kachergis, ${ }^{1}$ Maria E. Fernandez-Gimenez, ${ }^{2}$ and Monique E. Rocca ${ }^{3}$ \\ Authors are ${ }^{1}$ Postdoctoral Research Ecologist, USDA-ARS High Plains Grasslands Research Station, Cheyenne, WY 82009, USA; ${ }^{2}$ Associate Professor, \\ Department of Forest and Rangeland Stewardship, and ${ }^{3}$ Associate Professor, Department of Ecosystem Science and Sustainability, Colorado State \\ University, Fort Collins, CO 80523, USA.
}

\begin{abstract}
State-and-transition models (STMs), conceptual models of vegetation change based on alternate state theory, are increasingly applied as tools for land management decision-making. As STMs are created throughout the United States, it is crucial to ensure that they are supported by ecological evidence. Plant species composition reflects ecosystem processes that are difficult to measure and may be a useful indicator of alternate states. This study aims to create data-driven STMs based on plant species composition for two ecological sites (Claypan and Mountain Loam) in northwestern Colorado sagebrush steppe. We sampled 76 plots with different management and disturbance histories. Drawing on the hierarchical approach currently taken to build STMs, we hypothesized that A) differences in species composition between the two ecological sites would be related to environmental factors and B) differences in species composition within each ecological site would be related to management and disturbance history. Relationships among species composition, site history, and environmental variables were evaluated using multivariate statistics. We found that between ecological sites, species composition was related to differences in soil texture, supporting Hypothesis A and the creation of separate STMs for each site. Within ecological sites, species composition was related to site history and also to environmental variation. This finding partially supports Hypothesis B and the identification of alternate states using species composition, but also suggests that these ecological sites are not uniform physical templates upon which plant community dynamics play out. This data-driven, plant species-based approach created two objective, credible STMs with states and transitions that are consistent with the sagebrush steppe literature. Our findings support the hierarchical view of landscapes currently applied in building STMs. An approach that acknowledges environmental heterogeneity within ecological sites is necessary to help define finer-resolution ecological sites and elucidate cases in which specific abiotic conditions make transitions between states more likely.
\end{abstract}

\section{Resumen}

Los Modelos de Estado y Transición (MET), que son modelos conceptuales en cambios de la vegetación basados la teoría del estado alternativo, su aplicación está en aumento como herramienta para la tomada de decisiones en el manejo de la tierra. Como los MET se han creado a través de los Estados Unidos, es vital que aseguremos que estos están apoyados por evidencia ecológica. La composición de especies refleja el proceso del ecosistema que es difícil de medir y podría ser un indicador útil de estados alternativos. Este estudio ayuda a crear un MET dirigido por datos basado en las composición de especies de plantas de dos sitios ecológicos (Claypan y Mountain Loam) en la estepa de artemisa al noroeste de de Colorado. Muestramos 76 parcelas con diferente manejo e historias de disturbio. Dibujando el concepto jerárquico actualmente usado para construir los MET, establecimos las siguientes hipótesis A) Las diferencias en la composición de especies entre los dos sitios ecológicos podrían estar relacionadas a factores medioambientales y B) las diferencias en la composición de especies dentro de cada sitio ecológicos podrían estar relacionadas por el manejo y la historia de disturbio. Las relaciones entre la composición de especies, la historia del sitio y las variables medioambientales fueron evaluadas usando estadística multivariada. Encontramos que entre sitios ecológicos, la composición de especies estuvo relacionada con las diferentes texturas del suelo, apoyando la Hipotesis A y la creación de MET separados. Dentro de los sitios ecológicos, la composición de especies estuvo relacionada a la historia del sitio y también a variables medioambientales. Estos resultados apoyan parcialmente la Hipotesis B y la identificación de estados alternativos usando la composición de especies, pero también sugieren que estos sitios ecológicos no son uniformes en la plantilla física que es donde la dinámica de la comunidad vegetal se desenvuelve. Este concepto basado en datos dirigidos en especies de plantas creo dos objetivos, creíbles MET con estados y transiciones que son consistentes con la literatura de la estepa de artemisa. Nuestros resultados apoyan el punto de vista jerárquico de paisajes que se usan actualmente para construir MET's. Un enfoque que reconoce la heterogeneidad medioambiental dentro de sitios ecológicos es necesaria para ayudar a definir mejor resolución de sitios ecológicos y aclarar casos donde condiciones abióticas especificas hacen la transición mas probable.

Key Words: chemical shrub treatment, ecological site, multivariate statistics, northwest Colorado, rangeland management, state-and-transition model

Research was funded by the Colorado Agricultural Experiment Station (Project Number COL00698), a Natural Resource Conservation Service Colorado Conservation Innovation grant (AG-8B05-A-6-33), and a grant from the USDA National Research Initiative Managed Ecosystems Program (COL0-2008-00725).

At the time of research, Kachergis was a graduate research assistant, Graduate Degree Program in Ecology, Colorado State University, Fort Collins, C0 80523, USA.

Correspondence: Emily Kachergis, USDA-ARS High Plains Grasslands Research Station, Cheyenne, WY 82009, USA. Email: emily.kachergis@gmail.com

Manuscript received 1 August 2011; manuscript accepted 6 May 2012. 


\section{INTRODUCTION}

State-and-transition models (STMs), conceptual models of vegetation change based on alternate state theory, are increasingly applied as tools for land management decisionmaking (Westoby et al. 1989; Bestelmeyer et al. 2003; Suding and Hobbs 2009b). STMs describe threshold shifts in ecosystems, which are especially likely in semiarid rangelands with a short history of grazing such as the sagebrush steppe of western North America (Cingolani et al. 2005). Threshold shifts often have unexpected, negative impacts on ecosystem services (Scheffer et al. 2004). The US Department of Agriculture Natural Resources Conservation Service (NRCS) and partners are currently developing thousands of these models throughout the United States, and STMs are being developed and used in Mongolia, Africa, Australia, and elsewhere (Sasaki et al. 2008; Suding and Hobbs 2009a). Models are often developed based on expert knowledge with little published quantitative ecological evidence (Suding and Hobbs 2009b). As a consequence, the causes of vegetation change depicted in many models reflect assumptions grounded in mainstream range management ideas rather than empirically derived or tested relationships (Rodriguez Iglesias and Kothmann 1997). Recent efforts have focused on creating models based on ecological data (Bestelmeyer et al. 2009; Martin and Kirkman 2009; Petersen et al. 2009). This study evaluates variation in species composition as evidence of alternate states for two sagebrush steppe ecological sites.

Alternate state theory suggests that ecosystems are selforganizing, meaning that strong interactions among biotic and abiotic components drive dynamics. Feedback mechanisms associated with individual states either maintain a persistent state (self-arresting negative feedbacks) or cause transitions to other states (self-reinforcing positive feedbacks; Briske et al. 2006). In semiarid rangelands where resources are scarce, processes that influence water and nutrient storage in soils are major feedback mechanisms (e.g., infiltration; Huenneke et al. 2002; Rietkerk et al. 2004; Ludwig et al. 2005). Plant species composition is often related to differences in these key processes (Schlesinger et al. 1990; Blackburn et al. 1992; Rietkerk et al. 2004). Switches in feedbacks can be triggered by disturbances or management practices and cause transitions to other states. For example, increased grazing in Chihuahuan desert grasslands increases grass mortality and triggers soil erosion, causing a shift to a patchy shrubland alternate state (Schlesinger et al. 1990). The self-organizing view of rangeland dynamics predicts that areas with similar environmental characteristics can support multiple, relatively stable (selfreplacing) species assemblages that correspond to alternate states with unique feedback processes (Suding and Hobbs $2009 \mathrm{~b})$. Thus, if this view is correct, plots sampled at different locations can be grouped into alternate states based on species composition (Allen-Diaz and Bartolome 1998). The state of an area at a point in time should be determined by site history factors (i.e., disturbance and management history) that have brought the area to its current state (species assemblage).

Another view of ecosystem dynamics is that heterogeneity in abiotic factors such as soil texture drives differences in plant species composition and changes over time in different locations (Gleason 1926; Whittaker 1967). Plant species have different demographic survival and growth rates in different environments due to physiological constraints imposed by those environments (Gleason 1926; Whittaker 1967). For example, soil parent material is a factor in the "lithic inheritance" of a region, which controls particle size distribution and nutrient status, and different soils provide different amounts of water, nutrients, and anchorage for plants (Monger and Bestelmeyer 2006). According to this gradient view of the landscape, every location will differ slightly in soils and other site characteristics, and plant species composition and responses to disturbance are driven by these differences. Thus, differences in species composition in plots sampled at different locations should be related to environmental variation.

Evidence suggests that arid and semiarid landscapes are hierarchical: patterns arise from heterogeneity in abiotic factors at broader scales and from self-organizing dynamics driven by biotic and abiotic interactions at smaller scales (O'Neill et al. 1986; McAuliffe 1994; Bestelmeyer et al. 2006; Peters et al. 2006). The STM-building strategy being adopted by the NRCS and partners employs this hierarchy. Land is first classified into types with similar soils, climate, potential vegetation, and responses to management and disturbance, known as ecological sites (USDA-NRCS 2003; Bestelmeyer et al. 2009). Land within each ecological site is then classified into alternate states with different self-organizing processes (Bestelmeyer et al. 2009). In this study, we identify potential alternate states on two co-occurring ecological sites in the sagebrush steppe of northwestern Colorado (Fig. 1) using differences in plant foliar cover. Claypan is characterized by a thin clay loam or clay surface soil overlying deep clay subsoils, and is dominated by alkali sagebrush (Artemisia arbuscula Nutt. ssp. longiloba [Oster.] L.M. Shultz). Mountain Loam is characterized by loam or clay loam surface soils overlying deep clay loam or clay subsoils, with mountain big sagebrush (Artemisia tridentata Nutt. ssp. vaseyana [Rydb.] Beetle).

As with many efforts to create data-driven STMs, we use plant species composition as evidence of differences in processes and thus alternate states (Allen-Diaz and Bartolome 1998; Oliva et al. 1998; Jackson and Bartolome 2002; West and Yorks 2002). Species data are widely available, easy to collect, and relevant for range management. Multivariate statistical methods are often used for identifying potential alternate states and transition triggers. Identifying states using multivariate analyses, rather than a priori based on expert knowledge, helps free this process from subjectivity or bias (Foran et al. 1986; Allen-Diaz and Bartolome 1998). An "indirect gradient approach" relating species composition to multiple management and disturbance factors is desirable for building STMs because it examines trends in species composition as evidence of alternate states, rather than assuming a priori that states exist (Keddy 1991).

This paper has three objectives: 1) to describe the differences in soils and plant species composition between the two sagebrush steppe ecological sites, 2) to identify the major patterns in plant species composition within each ecological site and evaluate whether the self-organized or gradient view is supported by those patterns, and 3) to construct a data-driven STM for each ecological site. We sampled plots with similar climates but different management histories on two ecological sites to infer the effects of management on these areas. We 


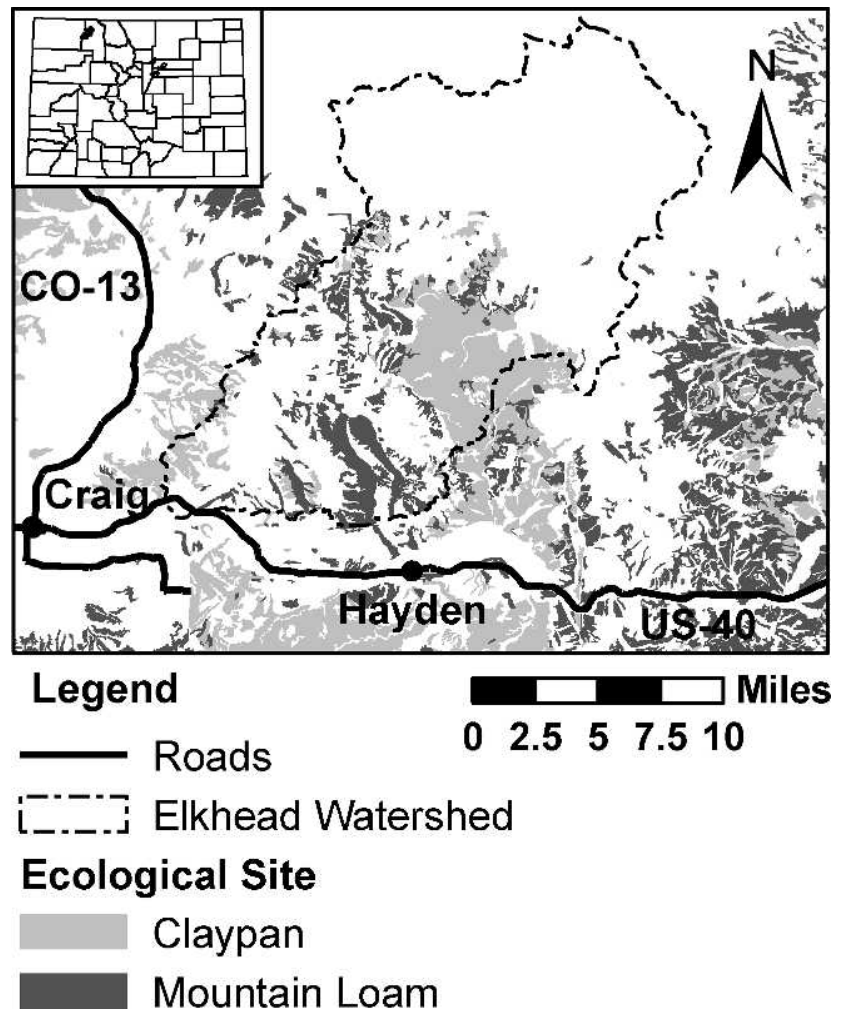

Figure 1. The Elkhead watershed in northwestern Colorado. Claypan and Mountain Loam ecological sites were mapped based on Natural Resources Conservation Service soil data. The Elkhead Mountains in the Routt National Forest (the area in white at the top of the map) were not considered in this study because the elevation and climate differed from those of our study area.

describe trends in plant species composition using ordination, and define potential states based on plant species composition using hierarchical cluster analysis. By relating species composition to site history as well as soil and environmental characteristics, we evaluate which view of ecosystem dynamics is supported at each scale: between ecological sites and within ecological sites. We predict that environmental factors drive differences in species composition between ecological sites (hypothesis A) but that, within ecological sites, species composition is related to disturbances and management factors that trigger transitions to alternate states (hypothesis B). Alternatively, if hypothesis A is false, then the abiotic factors on which these ecological sites are based are not good criteria for stratifying the landscape; if hypothesis B is false, then environmental context is an important driver of species composition even within environmentally similar ecological sites and differences represent environmentally driven vegetation types rather than alternate states. We use this approach to build and compare two data-driven STMs based on plant species composition.

\section{METHODS}

This study uses point samples of soils and vegetation with different site histories to infer the effects of management and disturbance on sites with similar environmental characteristics. Site selection and soil and plant species data collection methods are briefly described below and are reported by Kachergis et al. (2011).

\section{Site Selection}

Data were collected on private and public rangelands in and around the Elkhead watershed of northwestern Colorado (lat $40^{\circ} 38.5^{\prime} \mathrm{N}$, long $107^{\circ} 12.5^{\prime} \mathrm{W}$; Fig. 1). Fifteen private landowners and two public agencies (Bureau of Land Management and US Forest Service) participated in the study and provided information about management history (Knapp and FernandezGimenez 2009). Sampling focused on the Claypan and Mountain Loam ecological sites, two types of land with characteristic soils, climate, and vegetation (USDA-NRCS 2003). While these currently only exist as range sites, an earlier concept, we refer to them as ecological sites throughout the paper because this work is conceptually grounded in ecological sites and is meant to contribute toward developing the revised ecological site descriptions. Plot locations were stratified first by ecological site, and then by site history (management and disturbance): historic grazing intensity, a qualitative estimate of typical stocking rate based on interviews with 26 local land managers (Knapp 2008); cultivation/seeding history including enrollment in Conservation Reserve Program (CRP); burning by wildfire; and shrub management practices including aerial spraying, mechanical treatment, or none. We also measured distance from water, a proxy for grazing intensity (e.g., Bailey et al. 1996).

We sampled $7620 \times 50 \mathrm{~m}$ plots for vegetation in 2007 and 2008 and for soils in 2009.

\section{Soil and Site Characteristics}

Soil data were collected to validate that sampled plots matched the Claypan and Mountain Loam ecological sites, and to relate trends in species composition to soil variability. Soil descriptions following NRCS protocols (Schoeneberger et al. 1998) were based on a soil pit or auger hole $\geq 50 \mathrm{~cm}$ deep in the center of each plot. We recorded texture, structure, color, root density, and carbonates in each layer. The ecological site was verified by matching each soil description with the Claypan and Mountain Loam range site soil descriptions (USDA-SCS 1975). Plots were removed from analysis if their soil characteristics were unusual for these ecological sites (shallow, rocky, etc). Claypan is characterized by a thin clay loam or clay A horizon and a fine-textured subsoil that restricts water movement and availability; Mountain Loam is characterized by a thicker loam or clay loam A horizon and clay loam or clay subsurface.

Slope, aspect, and hillslope position were also recorded at each site. Aspect was transformed into a continuous variable with higher values for more productive northeastern slopes and low values for southwest slopes (Beers et al. 1966).

\section{Plant Species Composition}

We measured plant cover by species using the line-point intercept method, sampling at $1-\mathrm{m}$ intervals along five $50-\mathrm{m}$ transects spaced $5 \mathrm{~m}$ apart in the plot $(250$ points per plot; Bonham 1989). We recorded foliar and basal cover of plant species, litter, bare ground, and rock. Species names reported 
here correspond to the US Department of Agriculture PLANTS database (USDA-NRCS 2011b).

\section{Data Analysis}

To compare Claypan and Mountain Loam soils, we reported averages and standard errors for soil characteristics. We averaged over each of the top three soil horizons to give a general idea of the soil profiles and because we described these for all plots.

For multivariate analyses of plant cover data, plant cover values were square root transformed to reduce the influence of very common species. Species that occur in fewer than $5 \%$ of plots were omitted to reduce noise in the data (McCune and Grace 2002) and to ensure that more common species drove the definition of states. In addition, eight annual forb species were omitted because of differences in abundance in different sampling years. STMs are meant to describe long-term change, but interyear variation could give rise to states defined largely by ephemeral fluctuations.

We used nonmetric multidimensional scaling (NMS; Kruskal 1964) to describe the relationship between plant species composition and site history and environmental variables (hypotheses A and B). This indirect ordination method iteratively arranged plots in ordination space such that the distances between plots corresponded to the pair-wise dissimilarities in species composition between plots. Environmental and site history variables were correlated with ordination axes after the ordination was performed. If there were important variables that we did not measure, this method would reveal an unexplained trend in species data, unlike constrained ordination methods (e.g., canonical correspondence analysis). NMS also did not require assumptions about the underlying distribution of species along an environmental gradient, and was thus well suited for nonnormal data on discontinuous scales often found in community ecology. NMS was performed in $\mathrm{R}$ (version 2.13.1, The $\mathrm{R}$ Foundation for Statistical Computing) using package vegan (Oksanen et al. 2011). We used the Bray-Curtis distance measure, shared abundance divided by total abundance, because it performs well in community ecology analyses (Wishart 1969; McCune and Grace 2002). We chose the number of dimensions beyond which reductions in stress were less than five. Convergent solutions were identified from random starts through comparison of Procrustes residual mean square errors. We used a permutation test (1000 permutations) to assess significance of relationships between environment and site history variables and species composition, as shown by the ordination. Aggregate cover variables (e.g., shrub cover, basal litter cover) were also included to show differences in other ecosystem characteristics related to species composition. We reported correlation coefficients between variables and the ordination as well as significance levels from the permutation test.

Potential alternate states were identified using agglomerative hierarchical cluster analysis of plant species cover data in PCORD (version 5.0, MjM Software). Agglomerative hierarchical cluster analysis sequentially merged plots with similar species composition into larger groups (Dufrene and Legendre 1997; McCune and Grace 2002). We used the Bray-Curtis distance measure to calculate the plot dissimilarity matrix that was the basis for merging similar groups. We used the flexible beta linkage method (beta $=-0.25$ ) because this space-conserving method is compatible with Bray-Curtis distance (McCune and Grace 2002). Indicator species analysis, which generated an indicator value between 1 and 100 based on the faithfulness and exclusiveness of species to groups of plots, was used to prune the cluster dendrogram (Dufrene and Legendre 1997). Pruning occurred at the number of groups with the most significant indicator species (lowest average $P$ value for species based on a randomization test, 1000 randomizations), interpreted as the most ecologically meaningful number of groups (McCune and Grace 2002). Transitions between potential states were identified based on their management and disturbance histories and relationships to environmental variables. NMS facilitated this process by quantifying associations of particular management practices, disturbances, and environmental variables with variation in plant species composition. Before analysis, we tested for and failed to find any correlations between management practices and environmental variables.

We compared species composition between ecological sites and among potential states using pair-wise multiresponse permutation procedure (MRPP) on the Bray-Curtis distance with a Bonferroni correction in PC-ORD. MRPP tested the hypothesis of no differences among groups of plots (McCune and Grace 2002). This nonparametric method compared the observed weighted mean within-group distance in a distance matrix to the distance that would be expected by chance. The test statistic was the observed mean minus the expected mean divided by the expected standard deviation, similar to the Student's $t$. This test produced a $P$-value and a measure of effect size called the chance-corrected within-group agreement $(A)$ which ranged from 0 (no effect) to 1 . We used an alpha of 0.05 , and ecologically significant differences are often found when $A$ is $<0.1$ (McCune and Grace 2002).

\section{RESULTS}

\section{Comparing Soils and Plant Species Composition in two Ecological Sites}

Soils. We identified 41 Claypan and 35 Mountain Loam plots based on soil characteristics. The largest difference between soils in the two ecological sites was texture: Claypan had higher clay content in all horizons (Table 1). Other differences in soil properties were related to texture. Soil color was lighter in Claypan, indicating lower organic matter as expected on this less productive soil. Roots are generally more dense in Mountain Loam soils.

Trends in Species Composition. This analysis included all plots in the Claypan and Mountain Loam ecological sites $(N=76)$. Site history, environmental variables, and soil characteristics were included as possible explanatory variables. Aggregate cover variables (e.g., shrub cover, litter) were also included to show differences in other ecosystem characteristics related to species composition.

Species composition in the Claypan and Mountain Loam ecological sites differed more than expected by chance (MRPP; $A=0.08701 ; P<0.001)$. NMS showed that variation in species 
Table 1. Soil characteristics of Claypan and Mountain Loam plots in northwestern Colorado. For root density, numbers correspond to density classes as follows: 1 is $<1$ root $\cdot \mathrm{cm}^{-3}$ (few); 2 is $1-5$ roots $\cdot \mathrm{cm}^{-3}$ (common); 3 is $>5$ roots $\cdot \mathrm{cm}^{-3}$ (many). Carbonate stages are as follows: 0 is none; 1 is carbonate filaments and/or grain coatings; 2 is carbonate nodules.

\begin{tabular}{|c|c|c|c|c|}
\hline Soil property & Measurement & Horizon & Claypan (mean $\pm \mathrm{SE}$ or median) & Mountain Loam (mean $\pm \mathrm{SE}$ or median) \\
\hline \multirow[t]{4}{*}{ Texture } & $\%$ Clay (top $10 \mathrm{~cm}$ ) & - & $52.4 \pm 1.3$ & $30.9 \pm 1.6$ \\
\hline & $\%$ Clay & 1 & $42.8 \pm 1.9$ & $24.3 \pm 1.5$ \\
\hline & $\%$ Clay & 2 & $59.2 \pm 1.1$ & $36.3 \pm 2.0$ \\
\hline & $\%$ Clay & 3 & $63.9 \pm 0.8$ & $46.5 \pm 2.2$ \\
\hline \multirow[t]{2}{*}{ Thickness } & Thickness (cm) & 1 & $4.3 \pm 0.3$ & $5.4 \pm 0.6$ \\
\hline & Thickness (cm) & 2 & $12.1 \pm 1$ & $15.1 \pm 1.2$ \\
\hline \multirow[t]{6}{*}{ Color } & Value & 1 & 4 & 3 \\
\hline & Chroma & 1 & 2 & 2 \\
\hline & Value & 2 & 4 & 4 \\
\hline & Chroma & 2 & 3 & 2 \\
\hline & Value & 3 & 4 & 4 \\
\hline & Chroma & 3 & 3 & 3 \\
\hline \multirow[t]{6}{*}{ Root density } & Very fine roots & 1 & 2 & 3 \\
\hline & Fine roots & 1 & 2 & 2 \\
\hline & Very fne roots & 2 & 3 & 3 \\
\hline & Fine roots & 2 & 2 & 2 \\
\hline & Very fine roots & 3 & 2 & 2 \\
\hline & Fine roots & 3 & 1 & 2 \\
\hline Carbonates & Carbonate stage & 3 & 0 & 0 \\
\hline
\end{tabular}

composition was explained along two axes (76 plots, 75 species; final stress $=18.96$, two convergent solutions found after five tries; Fig. 2). The variation explained by the ordination, or the percentage of variation in dissimilarity explained by ordination distance, was $85 \%$. For each environmental variable, we report the short variable name listed in the ordination figures the first time it is mentioned, correlation coefficients with the ordination $(r)$ in the direction of most rapid change in the variable, and the level of significance based on 1000 permutations $(P)$. For management factors that were either applied or not applied (CRP, burning, mechanical treatment, and spraying), an increase in that factor along an axis indicates that application was positively correlated with that axis.

Axis 1 separated the Claypan from the Mountain Loam ecological site along a soil texture gradient. Field-determined percentage of clay in the top three soil horizons decreased with this axis (PctClay1, 2, and 3; $r=0.56,0.78$, and 0.74; $P<0.001)$. The value and chroma of the soil color in the first horizon and the chroma of the second soil horizon also decreased (Value1, Chroma1, Chroma2; $r=0.60, r=0.43$, $r=0.56 ; \mathrm{P}<0.001)$, indicating darker and less intense colors and higher organic matter accumulation. Basal cover of bare ground also decreased (BareGround; $r=0.38 ; P<0.01$ ) whereas total foliar plant cover, species richness, basal cover of litter, and very fine roots in the top horizon increased (PlantCover, Richness, Litter, VFRoots; $r=0.69$, 0.55, 0.50, and 0.48, respectively; $P<0.001)$. Claypan indicator species included alkali sagebrush (Artemisia arbuscula Nutt. ssp. longiloba [Oster.] L.M. Shultz), junegrass (Koeleria macrantha Ledeb. Schult.), and longleaf phlox (Phlox longifolia Nutt.), whereas Mountain Loam indicator species included mountain big sagebrush (Artemisia tridentata Nutt. ssp. vaseyana [Rydb.]

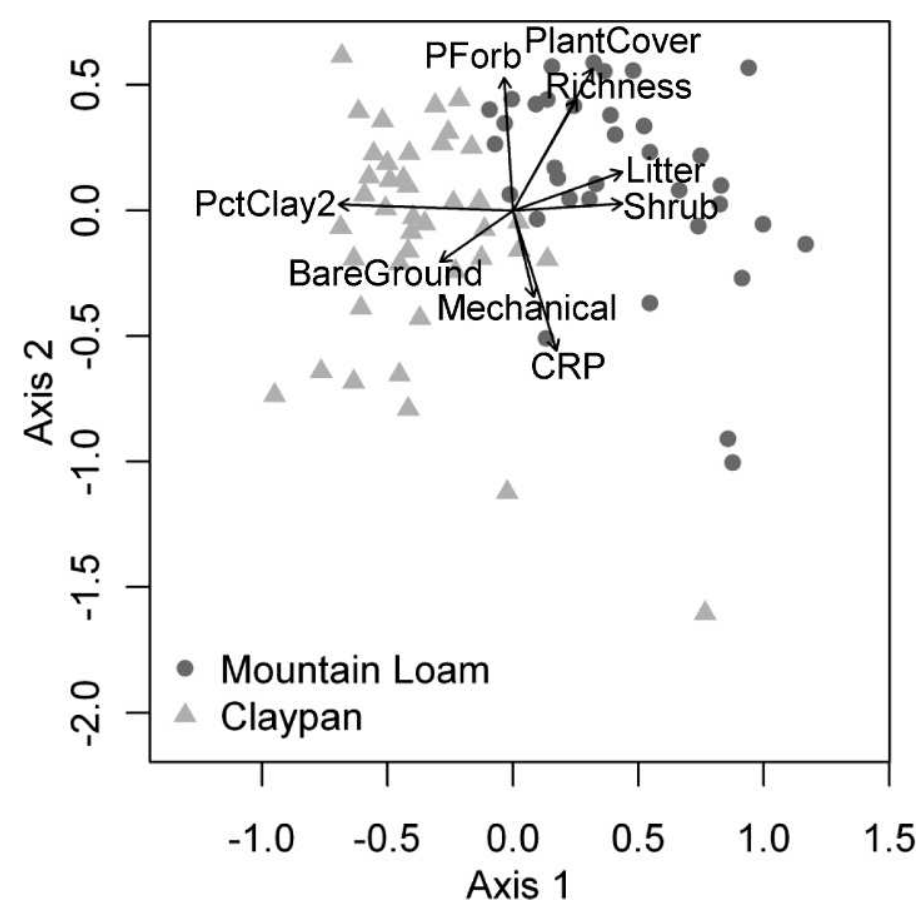

Figure 2. Differences in species composition and environmental variables between the Claypan and Mountain Loam ecological sites. Nonmetric multidimensional scaling results show differences in square root transformed plant species foliar cover for each plot, grouped by ecological site. Distances between plots (circles and triangles) are related to magnitude of differences in species composition. Vectors represent the direction and magnitude of correlations of other variables with species composition $(P<0.05)$. Many soil variables (e.g., color, root density) were correlated with texture (e.g., color, root density) so only percentage clay in the second horizon (PctClay2) is shown. Refer to the Results for full names and explanations of other variables. 
Beetle), snowberry (Symphoricarpos rotundifolius A. Gray), and yarrow (Achillea millefolium L.).

Axis 2 was related to seeding of forage grasses. CRP status was negatively related to this axis (CRP; $r=0.63 ; P<0.001)$, as was the one non-CRP seeded site. Application of mechanical treatment was also negatively related to this axis (Mechanical; $r=0.38, P<0.01$ ), since several seeded plots were mechanically treated. In contrast, cover of perennial forbs increased (PForb; $r=0.57 ; P<0.001$ ) as did total plant cover and species richness. Planted Grasslands (four plots at the bottom of Fig. 2) were significantly different in species composition from all other plots $(A=0.0402, P<0.001)$. Indicator species of these grasslands were the nonnative grasses intermediate wheatgrass (Thinopyrum intermedium [Host] Barkworth \& D.R. Dewey) and smooth brome (Bromus inermis Leyss.) as well as the native grasses thickspike wheatgrass (Elymus lanceolatus [Scribn. \& J.G. Sm.] Gould) and bluebunch wheatgrass (Pseudoroegneria spicata [Pursh] Á. Löve). Planted Grasslands were removed from subsequent analyses because of their difference in species composition.

\section{Trends in Species Composition Within Ecological Sites}

Claypan Ecological Site. Hierarchical cluster analysis and indicator species analysis (ISA) of species composition by plot identified potential alternate states. Seven groups had the lowest average $P$ value for species based on the randomization test (ISA; $P=0.13$ ). We combined two groups that were similar in species composition and characteristics except for differences in ephemeral forb cover related to a late, moist spring in one sampling year. The resulting six potential states, referred to by their short names in parentheses from here on, were diverse alkali sagebrush shrubland (Diverse), alkali sagebrush/bluegrass shrubland (Bluegrass), alkali sagebrush/western wheatgrass shrubland (Wheatgrass), native grassland (Native Grassland), three-tip/mountain big sagebrush shrubland (Three-tip), and alkali sagebrush shrubland with sparse understory (Sparse). Indicator species for each state are listed in Table 2. The within-group similarity in species composition was greater than expected by chance (MRPP; $A=0.2103$; $P<0.0001$ ), and most groups were significantly different in species composition when compared pair-wise (Table 3). The largest differences in species composition were between Sparse and other potential states (Table 3).

NMS identified major trends in species composition and associations with site history and environmental variables for Claypan potential states. The final stress for the threedimensional NMS solution was 14.37 on 39 plots and 41 species (Fig. 3). The cumulative variation in plant species composition explained by the three axes was $86 \%$. Along axis 1 , shrub cover (Shrub; $r=0.81, P<0.001$ ) increased and perennial grass cover (PGrass; $r=0.81, \mathrm{P}<0.001$ ) decreased. Aerial spraying (Spray; $r=0.74, P<0.001$ ) decreased with this axis, meaning that application of this practice is negatively correlated to this axis. With axis 2, basal bare ground cover increased $(r=0.55 ; P<0.01)$ as did perennial forb cover $(r=0.71 ; P<0.001)$. Mechanical treatment decreased with this axis $(r=0.44 ; P<0.05)$. With axis 3 , perennial forb cover increased as did spraying. Shrub cover and lack of shrub management were inversely related to axis 3 (NoShrub Mgmt; $r=0.67, P<0.001$ ). Aspect also increased with axis 3 (Aspect; $r=0.45 ; P<0.05)$. Proxies for grazing intensity were not related to trends in species composition.

Factors that influence transitions were suggested by the NMS and the management histories of the potential states (Table 2). The Grassland potential state was associated with aerial spraying of herbicide. Two out of four Three-tip plots were mechanically treated. The Bluegrass, Wheatgrass, and Diverse states overlap on the ordination and were not associated with site history. The Sparse potential state differed the most in species composition from all other potential states and was related to lack of shrub management.

Mountain Loam Ecological Site. Hierarchical cluster analysis and ISA of species composition by plot identified potential alternate states. Five groups had the lowest average $P$ values for all species according to the randomization test (ISA; $P=0.26$ ), so the cluster dendrogram was pruned at this level. The resulting potential states, hereafter referred to by their short names in parentheses, were diverse mountain big sagebrush shrubland (Diverse), mountain big sagebrush/western wheatgrass shrubland (Wheatgrass), three-tip/mountain big sagebrush shrubland (Three-tip), mountain big sagebrush shrubland with sparse understory (Sparse), and dense mountain big sagebrush shrubland (Dense). Indicator species for each state were listed in Table 2. The within-group similarity in species composition was greater than expected by chance (MRPP; $A=0.1889 ; P<0.0001$ ), and all groups were significantly different in species composition when compared pairwise (Table 4). Differences were greatest when comparing Dense to all other groups (Table 4).

NMS identified major trends in species composition and associations with site history and environmental variables for Mountain Loam potential states. The final stress for the threedimensional NMS solution on 33 plots and 53 species was 13.58 and two convergent solutions were found after two iterations (Fig. 4). The cumulative variation explained by the ordination was $87 \%$. With axis 1 , perennial forb cover decreased $(r=0.83 ; P<0.001)$ and shrub cover increased $(r=0.62 ; P<0.01)$. Field-determined percentage of clay in the second and third horizons decreased $(r=0.53,0.61$; $P<0.05,0.01)$. Spraying was negatively associated with this axis but the relationship was marginally significant $(r=0.46$; $P=0.07)$. With axis 2 , perennial forb cover decreased and perennial grass cover increased $(r=0.73, P<0.001)$. Burning decreased with this axis (Burn; $r=0.66 ; P<0.001$ ). With axis 3 , perennial forb cover increased and grass cover decreased. Species richness increased with this axis $(r=0.49, P<0.05)$. Lack of shrub treatment was positively related to this axis $(r=0.60, P<0.01)$ and burning and spraying were negatively related to this axis. Mechanical treatment and proxies for grazing intensity were not related to trends in species composition.

Factors that influence transitions are suggested by the NMS and the site histories of potential states (Table 2). Aerial spraying of herbicides was associated with the Diverse state. Two burned plots fell into the Sparse potential state. One mechanically treated plot was in the Three-tip potential state. The Dense potential state was related to a lack of shrub management or disturbance-one plot is known to have 
Table 2. Potential alternate states of the Claypan and Mountain Loam ecological sites with associated indicator species according to indicator species analysis $(P<0.05)$ and management history. Potential alternate states were identified using hierarchical cluster analysis of plant species cover by plot. Species names are from the USDA PLANTS database (USDA-NRCS 2011b).

\begin{tabular}{|c|c|c|c|}
\hline & $\begin{array}{l}\text { No. of } \\
\text { plots }\end{array}$ & Indicator species $(P<0.05)$ & Management history (no. of plots) \\
\hline \multicolumn{4}{|l|}{ Claypan potential states } \\
\hline $\begin{array}{l}\text { Alkali sagebrush shrubland with } \\
\text { diverse understory }\end{array}$ & 3 & $\begin{array}{l}\text { Melica bulbosa Geyer ex Porter \& J.M. Coult, Helianthella uniflora (Nutt.) } \\
\text { Torr. \& A. Gray, Perideridia gairdneri (Hook. \& Arn.) Mathias, Elymus } \\
\text { elymoides (Raf.) Swezey, Achnatherum lettermanii (Vasey) Barkworth, } \\
\text { Artemisia tridentata Nutt. ssp. vaseyana (Rydb.) Beetle, } \\
\text { Symphoricarpos rotundifolius A. Gray }\end{array}$ & $\begin{array}{l}\text { Ungrazed for } 10 \mathrm{yr}(1) \text {; low grazing } \\
\text { intensity (2) }\end{array}$ \\
\hline Native grassland & 10 & Koeleria macrantha (Ledeb.) Schult., Phlox Iongifolia Nutt. & Sprayed (8) \\
\hline $\begin{array}{l}\text { Alkali sagebrush/ bluegrass } \\
\text { shrubland }\end{array}$ & 5 & Poa secunda J. Presl & $\begin{array}{l}\text { Sprayed }(2) ; \text { low-medium }(1) \text {, high } \\
\quad \text { grazing intensity }(4)\end{array}$ \\
\hline $\begin{array}{l}\text { Alkali sagebrush/ western } \\
\text { wheatgrass shrubland }\end{array}$ & 11 & $\begin{array}{l}\text { Pascopyrum smithii (Rydb.) Á. Löve, Astragalus wetherillii M.E. Jones, } \\
\text { Lomatium grayi (J.M. Coult. \& Rose) J.M. Coult. \& Rose, Microseris } \\
\text { nutans (Hook.) Sch. Bip. }\end{array}$ & $\begin{array}{l}\text { Sprayed (1); medium (5), medium-high } \\
\text { (2), high (4) grazing intensity }\end{array}$ \\
\hline $\begin{array}{l}\text { Three-tip/mountain big sagebrush } \\
\text { shrubland }\end{array}$ & 4 & $\begin{array}{l}\text { Artemisia tripartita Rydb., Poa nemoralis L. ssp. interior (Rydb.) } \\
\text { W.A.Weber, Achillea millefolium L., Bromus tectorum L. }\end{array}$ & $\begin{array}{l}\text { Mechanical treatment of shrubs (2); low } \\
\text { (1), medium-high (1), high (2) grazing } \\
\text { intensity }\end{array}$ \\
\hline $\begin{array}{l}\text { Alkali sagebrush shrubland/sparse } \\
\text { understory }\end{array}$ & 6 & $\begin{array}{l}\text { Artemisia arbuscula Nutt. ssp. Iongiloba (Oster.) L.M. Shultz, Arenaria } \\
\text { hookeri Nutt., Gutierrezia microcephala (DC.) A. Gray, Orthocarpus } \\
\text { luteus Nutt. }\end{array}$ & $\begin{array}{l}\text { Burn } \sim 10 \text { yr ago (1); low (1), medium } \\
\quad(2), \text { medium-high (2), high (2) grazing } \\
\text { intensity }\end{array}$ \\
\hline \multicolumn{4}{|l|}{ Mountain Loam potential states } \\
\hline $\begin{array}{l}\text { Mountain big sagebrush shrubland } \\
\text { with diverse understory }\end{array}$ & 7 & $\begin{array}{l}\text { Symphyotrichum spathulatum (Lindl.) G.L. Nesom, Melica bulbosa Geyer } \\
\text { ex Porter \& J.M. Coult, Achillea millefolium L., Achnatherum } \\
\text { lettermanii (Vasey) Barkworth, Symphoricarpos rotundifolius A. Gray }\end{array}$ & $\begin{array}{l}\text { Sprayed (5); Low-Med (2), medium-high } \\
\text { (5) Grazing Intensity }\end{array}$ \\
\hline $\begin{array}{l}\text { Mountain big sagebrush/western } \\
\text { wheatgrass shrubland }\end{array}$ & 12 & $\begin{array}{l}\text { Lomatium grayi (J.M. Coult. \& Rose) J.M. Coult. \& Rose, Microseris } \\
\text { nutans (Hook.) Sch. Bip., Astragalus wetherillii M.E. Jones, Wyethia } \\
\text { amplexicaulis (Nutt.) Nutt. }\end{array}$ & $\begin{array}{l}\text { Sprayed (2); Low-Med (6), medium-high } \\
\text { (3), High (3) Grazing Intensity }\end{array}$ \\
\hline $\begin{array}{l}\text { Three-tip/mountain big sagebrush } \\
\text { shrubland }\end{array}$ & 4 & $\begin{array}{l}\text { Artemisia tripartita Rydb., Phleum pratense L., Poa nemoralis L. ssp. } \\
\text { interior (Rydb.) W.A.Weber }\end{array}$ & $\begin{array}{l}\text { Mechanical Treatment (1); Low-Med (2), } \\
\text { medium-high (1), High (1) Grazing } \\
\text { Intensity }\end{array}$ \\
\hline $\begin{array}{l}\text { Mountain big sagebrush shrubland/ } \\
\text { sparse understory }\end{array}$ & 5 & $\begin{array}{l}\text { Chrysothamnus viscidiflorus (Hook.) Nutt., Leymus cinereus (Scribn. \& } \\
\text { Merr.) Á. Löve, Erodium cicutarium (L.) L’Hér. ex Aiton }\end{array}$ & $\begin{array}{l}\text { Burned } 2 \text { yr ago (2); Low-Med (2), } \\
\text { medium-high (2), High (1) Grazing } \\
\text { Intensity }\end{array}$ \\
\hline $\begin{array}{l}\text { Dense mountain big sagebrush } \\
\text { shrubland }\end{array}$ & 5 & $\begin{array}{l}\text { Artemisia tridentata Nutt. ssp. vaseyana (Rydb.) Beetle, Bromus } \\
\text { marginatus Nees ex Steud. }\end{array}$ & $\begin{array}{l}\text { Low-Med (1), medium-high (1), High (3) } \\
\text { Grazing Intensity }\end{array}$ \\
\hline Planted grasslands (both soil types) & 4 & $\begin{array}{l}\text { Thinopyrum intermedium (Host) Barkworth \& D.R. Dewey), Bromus } \\
\text { inermis Leyss., Elymus lanceolatus (Scribn. \& J.G. Sm.) Gould, } \\
\text { Pseudoroegneria spicata (Pursh) Á. Löve }\end{array}$ & $\begin{array}{l}\text { Seeded with non-native grasses (4); CRP } \\
\text { (2); sprayed and mechanically treated } \\
\text { (1); Burned } \sim 10 \text { yr ago (1) }\end{array}$ \\
\hline
\end{tabular}

Table 3. Differences in species composition between potential states for the Claypan Ecological Site according to multiresponse permutation procedure. Chance-corrected within-group agreement $(A)$ values are in italics; $A$ values of 1 indicate that all plots within a group have identical composition, whereas $A$ values of 0 indicate that heterogeneity within groups equals that expected by chance. $P$ values in bold are significant at Bonferroni corrected $P<0.0033$.

\begin{tabular}{lcccrr}
\hline & Grassland $^{1}$ & Bluegrass & Wheatgrass & Three-tip & Sparse \\
\hline Diverse & $0.1336 \mathbf{0 . 0 0 0 5}$ & 0.10240 .0079 & 0.06370 .0050 & 0.17770 .0095 & 0.13690 .0061 \\
Grassland & - & $0.1036 \mathbf{0 . 0 0 0 4}$ & $0.0758 \mathbf{0 . 0 0 0 0}$ & $0.1133 \mathbf{0 . 0 0 0 4}$ & $0.2354 \mathbf{0 . 0 0 0 0}$ \\
Bluegrass & - & - & $0.1021 \mathbf{0 . 0 0 0 2}$ & 0.15320 .0035 & $0.1211 \mathbf{0 . 0 0 0 7}$ \\
Wheatgrass & - & - & - & $0.1173 \mathbf{0 . 0 0 0 1}$ & $0.1864 \mathbf{0 . 0 0 0 0}$ \\
Three-tip & - & - & - & - & $0.2409 \mathbf{0 . 0 0 1 3}$ \\
\hline
\end{tabular}

${ }^{1}$ Diverse indicates alkali sagebrush shrubland with diverse understory; grassland, native grassland; bluegrass, alkali sagebrush/bluegrass shrubland; wheatgrass, alkali sagebrush/western wheatgrass shrubland; three-tip, three-tip/mountain big sagebrush shrubland; sparse, alkali sagebrush shrubland/sparse understory. 


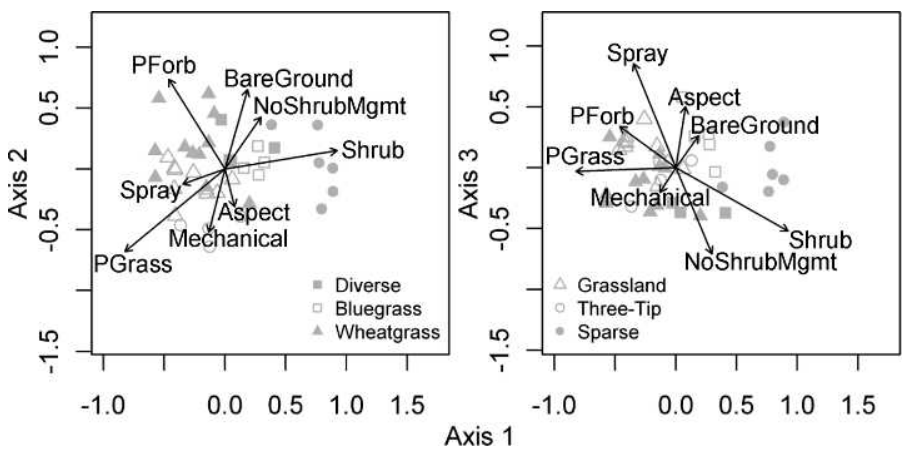

Figure 3. Nonmetric multidimensional scaling results for plant species foliar cover by plot in the Claypan ecological site. Symbols represent plots, with different symbols for plots in different potential states identified using hierarchical cluster analysis. Distances between plots are related to magnitude of differences in species composition. Vectors show direction and magnitude of correlations $(P<0.05)$ between the ordination and environmental and site history variables. Many soil variables (e.g., color, root density) were correlated with texture so only percentage clay in the second horizon (PctClay2) is shown. Refer to the Results for full names and explanations of other variables.

burned 60 yr ago. In addition to site history, potential states were related to soil texture, with the Wheatgrass potential state at the clayey end of the gradient and Dense and Sparse at the less clayey end.

\section{DISCUSSION}

\section{Soil Texture and Seeding Drive Species Differences Between Ecological Sites}

The main difference between Claypan and Mountain Loam soils was texture, consistent with previous comparisons of alkali and mountain big sagebrush-dominated sites (Robertson et al. 1966) and the ecological site descriptions (USDA-SCS 1975). Mountain Loam soils were more heterogeneous than Claypan soils, something that is evident also in the greater variety of soils that are classified as Mountain Loam in NRCS soil maps (USDA-NRCS 2009).

Differences in plant species composition were associated with different soil characteristics and ecological sites, support-

Table 4. Differences in species composition between potential states for the Mountain Loam Ecological Site according to multiresponse permutation procedure. Chance-corrected within-group agreement $(A)$ values are in italics; $A$ values of 1 indicate that all plots within a group have identical composition, whereas $A$ values of 0 indicate that heterogeneity within groups equals that expected by chance. $P$ values in bold are significant at Bonferroni corrected $P<0.0050$.

\begin{tabular}{lcccc}
\hline & Wheatgrass $^{1}$ & Three-tip & Sparse & Dense \\
\hline Diverse & $0.0659 \mathbf{0 . 0 0 0 1}$ & $0.1501 \mathbf{0 . 0 0 1 0}$ & $0.1085 \mathbf{0 . 0 0 1 0}$ & $0.2107 \mathbf{0 . 0 0 0 4}$ \\
Wheatgrass & & $0.1052 \mathbf{0 . 0 0 0 1}$ & $0.1018 \mathbf{0 . 0 0 0 0}$ & $0.1508 \mathbf{0 . 0 0 0 0}$ \\
Three-tip & & & $0.1847 \mathbf{0 . 0 0 2 4}$ & $0.1870 \mathbf{0 . 0 0 2 7}$ \\
Sparse & & & & $0.1074 \mathbf{0 . 0 0 3 2}$
\end{tabular}

\footnotetext{
${ }^{1}$ Wheatgrass indicates alkali sagebrush/western wheatgrass shrubland; three-tip, three-tip/ mountain big sagebrush shrubland; sparse, mountain big sagebrush shrubland/sparse understory; dense, dense mountain big sagebrush shrubland.
}

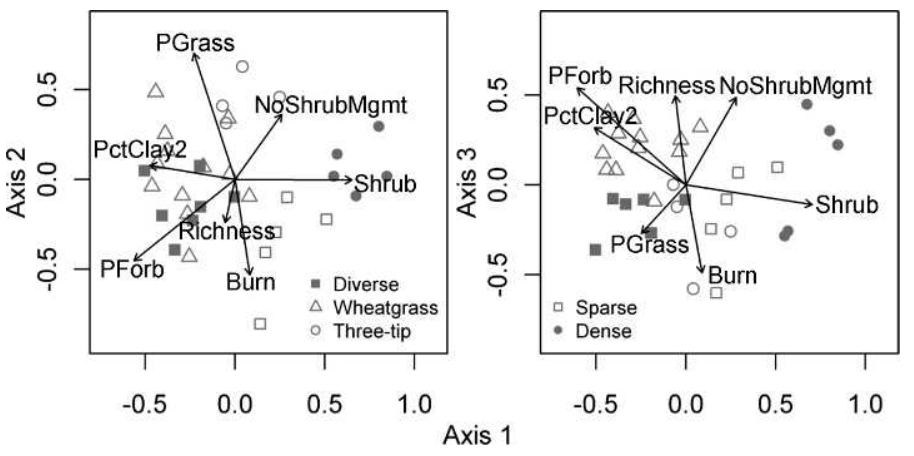

Figure 4. Nonmetric multidimensional scaling results for plant species foliar cover by plot in the Mountain Loam ecological site. Symbols represent plots, with different symbols for plots in different potential states identified using hierarchical cluster analysis. Distances between plots are related to magnitude of differences in species composition. Vectors show direction and magnitude of correlations $(P<0.05)$ between the ordination and environmental and site history variables. Many soil variables (e.g., color, root density) were correlated with texture so only percentage of clay in the second horizon (PctClay2) is shown. Refer to the Results for full names and explanations of other variables.

ing our prediction that larger-scale patterns in species composition are driven by soil, climate, and topographic heterogeneity, as represented by ecological sites (hypothesis A). This is consistent with the distribution of the dominant sagebrush species in these ecological sites: they occur at similar temperature and moisture regimes, but alkali sagebrush prefers heavy clay soils, whereas mountain big sagebrush grows in a range of textures from clay loams to loams (Robertson et al. 1966; West and Young 2000; Winward 2004). Previous studies have shown that herbaceous plant composition in adjacent dwarf and big sagebrush communities is different although it overlaps partially (Robertson et al. 1966; Burke et al. 1989). In addition to species differences, Mountain Loam plots had higher shrub and total foliar cover and higher species richness. These are consistent with the increased water infiltration and storage due to the more coarse surface texture over a relatively fine subsurface texture in Mountain Loam vs. Claypan (Robertson et al. 1966; Schaetzl and Anderson 2005).

The other major difference in plant species composition across ecological sites was related to formerly cultivated plots that had been seeded with grasses. Species composition in Claypan and Mountain Loam seeded grasslands were similar, despite the difference in soils. This likely reflects similar initial species seeded at these plots, taken from a recommended species list. Christian and Wilson (1999) similarly found that seeded species persisted for at least $50 \mathrm{yr}$ after planting into abandoned agricultural lands. Although the soils are different, the mediumterm $(25+\mathrm{yr})$ effects of this management practice on species composition appear generalizable across ecological sites.

\section{Site History and Environment Drive Species Differences Within Ecological Sites}

Species composition was related to both site history and environmental variation in both ecological sites. In Claypan, three site history variables (spraying, mechanical treatment, and lack of shrub treatment) and one environmental variable 
(aspect) were related to differences in species composition. Mountain Loam species composition was related to two site history variables (burning and lack of shrub treatment) and two environmental variables (soil texture in the second and third horizons). This finding is contrary to our prediction that species composition within an ecological site is related to differences in management and process and not to heterogeneity in abiotic factors (hypothesis B), a hypothesis that is inherent in the way STMs are created and used. Relationships to management and environmental variation indicate that although the selforganized plant community dynamics suggested by alternate state theory may occur (Suding et al. 2004), with endogenous biotic and abiotic interactions driving dynamics at the plot scale, environmental heterogeneity also plays a role in determining species composition within these ecological sites.

Two mechanisms likely give rise to this finding. First, environmental gradients may influence potential vegetation within these ecological sites (e.g., Gleason 1926), suggesting that they are defined too broadly. Claypan and Mountain Loam are defined by the dominant sagebrush species and their associated soils (Robertson et al. 1966; USDA-SCS 1975), under the assumption that these areas have the same potential vegetation and response to management. However, many herbaceous understory species occur within a different range of environmental characteristics than sagebrush species (Passey and Hugie 1962; Robertson et al. 1966; USDA-SCS 1975). On the landscape, we and others have found that locations with the same sagebrush species and site history often have different understory species (Passey et al. 1982; Burke et al. 1987; Ewers and Pendall 2008); for example, western wheatgrass is more common on clayey soils within Mountain Loam. For ecological sites defined by sagebrush species, the assumption of the same potential vegetation (defined as species composition) may not hold. A second mechanism is that environmental characteristics may interact with site history factors to make certain transitions more likely on certain sites (e.g., Peters et al. 2006). For example, studies have shown that rangeland erosion is more likely on steep slopes, after fire (Pierson et al. 2008), and with heavier grazing (Fynn and O'Connor 2000). Likewise, rangeland health indicators suggest that erosion is an important process on the Sparse Claypan state, which occurs on steeper slopes (Kachergis et al. 2011). Future work is needed to establish the relationships between environmental gradients and self-organizing plant community dynamics on these ecological sites and to distinguish between these mechanisms.

Splitting Claypan and Mountain Loam into finer-scale ecological sites that encompass less variation may minimize cases in which environmental conditions influence the potential species pool within ecological sites. Indeed, current efforts are identifying multiple ecological sites dominated by mountain big sagebrush within the same climate region (USDA-NRCS 2011a). However, splitting ecological sites may not account for cases where interactions between management and environmental variation trigger transitions, especially when the likelihood of transitions varies along an environmental gradient. As ecological sites and STMs are refined, it is critical to track the influence of environmental gradients on species composition, in addition to management effects.

In this study, we chose variables relevant to species composition in the sagebrush steppe with the aim of producing

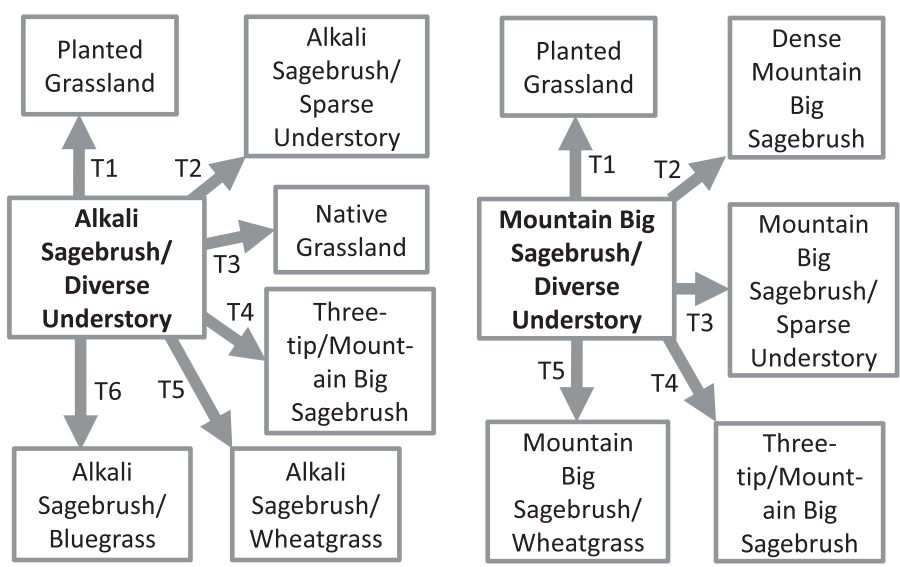

Figure 5. Data-driven state-and-transition models for the Claypan and Mountain Loam ecological sites in northwestern Colorado. Boxes are potential alternate states with different species composition identified using hierarchical cluster analysis. Arrows mark associations with site history and environmental variation that may make transitions more likely; these were identified using nonmetric multidimensional scaling and qualitative analysis (Figs. 2-4; Table 2). Transitions are listed in Table 5.

a methodology that could be broadly applied for STM development. We cannot rule out the possibility that unmeasured environmental or site history variables may cause species differences that we observed here. Nevertheless, trends in species composition within these ecological sites show that although many inferences about response to management can be drawn even from imperfect ecological sites, environmental variables are also important for understanding species composition in ecological site and STM development.

\section{Two Ecological Sites Have Similar and Contrasting States and Dynamics}

Based on relationships among species composition-derived potential states and site history variables (Figs. 3 and 4; Table 2 ), we constructed two STMs of responses to management and disturbance for the Claypan and Mountain Loam ecological sites (Fig. 5; Table 5). Management actions and disturbances were associated with potential states, consistent with the STM framework. Environmental heterogeneity also has an influence and is noted within the models.

Comparison between the two STMs reveals many similarities in the effects of management on these ecological sites. The Diverse potential states in both ecological sites had greater cover of perennial plants and species richness than most other groups (Claypan: $73 \%$ average cover and 38 species; Mountain Loam: $75 \%$ average cover and 41 species), granular soil structure, higher organic matter content, and no invasive species, consistent with others' descriptions of "reference states" (USDA-NRCS 2003) for sagebrush steppe (Supplement 1; available online at http://dx.doi.org/10.2111/REM-D-11-00137.s1; Blaisdell 1953; Ellison 1960; Passey and Hugie 1962). Wheatgrass potential states were the most frequent and were similar to reference states except for the dominance of western wheatgrass (Claypan: 80\% of perennial grass cover and Mountain Loam: 30\%) and lower sagebrush cover. Others have reported a wheatgrass-dominated 
Table 5. Transitions between states of the Claypan and Mountain Loam ecological site (Fig. 5) based on this study.

\begin{tabular}{ll}
\hline & \multicolumn{1}{c}{ Claypan Transitions } \\
\hline $\begin{array}{l}\text { Maintenance of } \\
\text { diverse state }\end{array}$ & No grazing to low long-term grazing intensity \\
T1 & Planting nonnative grasses (includes CRP) \\
T2 & Lack of shrub disturbance (spraying or fire) \\
T3 & Aerial spraying with herbicide \\
T4 & Mechanical treatment \\
T5 & Moderate to high long-term grazing intensity \\
T6 & High long-term grazing intensity; also associated with \\
& spraying shrubs, but alkali sagebrush still present \\
& \\
& Mountain Loam Transitions \\
\hline Maintenance of & Aerial spraying with herbicide and sagebrush \\
diverse state & re-colonization after $>10$ yr \\
T1 & Planting nonnative grasses (includes CRP) \\
T2 & Lack of shrub disturbance (spraying or fire); more likely with \\
& less clayey soil textures \\
T3 & Recent fire; also associated with steep slopes between \\
T4 & agricultural fields \\
T5 & Weakly associated with mechanical treatment \\
T6 & Low to moderate long-term grazing; higher soil clay content \\
\hline
\end{tabular}

state in Wyoming big sagebrush steppe related to heavy spring grazing (Cagney et al. 2010); more research is needed to establish this link on these ecological sites. Three-tip sagebrush potential states were associated with mechanical treatment on both soil types, consistent with others' findings that this resprouting shrub is associated with recent disturbance (Passey and Hugie 1962; Winward 2004).

Several key differences in response to management justify division of Claypan and Mountain Loam into two ecological sites (USDA-NRCS 2003). Spraying herbicides that kill shrubs had a different effect on the two soil types. Claypan plots that were sprayed 20+ yr ago were persistent Native Grasslands (41\% average perennial grass cover, $4 \%$ shrub) and Mountain Loam plots were Diverse shrublands with abundant resprouting shrubs and forbs $(27 \%$ average shrub cover, $26 \%$ forb, $23 \%$ grass). Growing in a more mesic soil environment, mountain big sagebrush and resprouting shrubs likely reestablish faster than alkali sagebrush; mountain big sagebrush is known to recolonize sprayed areas within 10-15 yr (Thilenius and Brown 1974; Sturges 1993). The Claypan Bluegrass potential state was similar to Diverse except for a more homogeneous understory of Sandberg bluegrass (Poa secunda J. Presl; $27 \%$ of total grass cover on average); it had no analogue in Mountain Loam. Similarly, the Mountain Loam Sparse potential state was similar to the Dense but with lower grass cover; it had no analogue in Claypan.

The largest differences in species composition within both ecological sites were related to lack of shrub disturbance. The Sparse Claypan potential state and the Dense Mountain Loam potential state were the most different from all others, with the highest shrub cover $(31 \%$ and $42 \%$ average) and low herbaceous cover $(16 \%$ and $31 \%$ average; Supplement 1$)$. Similar dense stands of sagebrush associated with depleted grass and forb understories are well documented in sagebrush rangelands and can persist for long periods even when grazing has been removed (Blaisdell 1953; Ellison 1960; Zamora and Tueller 1973; Anderson and Holte 1981). This condition has been attributed to two interrelated factors: 1) fire suppression and 2) heavy grazing (Miller et al. 1994). Our findings are consistent with others' observations that in the absence of site history factors that reduce shrub cover and in the presence of summer grazing, mountain big sagebrush and alkali sagebrush can form dense stands with few understory fine fuels. These stands may form a fire-resistant plant community that further promotes shrub dominance.

Measures of grazing intensity at each plot (distance from water and historic grazing intensity) did not show strong associations with species composition, despite the findings of other studies in sagebrush rangelands (Miller et al. 1994; Bork et al. 1998). Grazing patterns are a complex function of landscape characteristics and animal behavior that are difficult to approximate with simple measures (Bailey et al. 1996). The relatively strong effects of other management practices such as spraying also may obscure the effects of grazing on species composition, especially in the correlational framework employed here. Controlled grazing experiments, a sampling scheme that explicitly addresses grazing patterns, and/or expert and local knowledge are needed to better understand the influence of grazing on these plant communities.

\section{IMPLICATIONS}

In their 1966 paper comparing rangelands dominated by alkali vs. big sagebrush in North Park, Colorado, Robertson and others found a "direct relationship between range sites and soils." More than $40 \mathrm{yr}$ later, as part of the effort to update range sites to ecological sites, this study supports their division of lands dominated by these sagebrush species into Claypan and Mountain Loam ecological sites with different soils and potential vegetation, but also suggests further division may improve our understanding of the effects of management. We examined variation in species composition within these two ecological sites as an indicator of vegetation dynamics for building STMs. Species composition within both ecological sites was related to site history and environmental variation. This suggests that although species composition is useful for creating data-driven STMs in the sagebrush steppe, a modelbuilding approach that acknowledges environmental heterogeneity is necessary to 1 ) ensure that heterogeneity is not driving differences in potential species composition, indicating that ecological sites may need to be split, and 2) elucidate cases in which specific abiotic conditions make transitions more likely. Different dynamics on the two different ecological sites support the creation of separate STMs for different ecological sites, as currently applied in building STMs (e.g., Bestelmeyer et al. 2009).

The approach presented here, comparing species composition in areas that have been managed differently, is one helpful tool in a diverse toolbox for understanding complex landscapes. These STMs will benefit from integration with and 
validation by additional types of information, including expert and local knowledge (Knapp and Fernandez-Gimenez 2009; Knapp et al. 2011), long-term monitoring data (Allen-Diaz and Bartolome 1998), experiments (Martin and Kirkman 2009), and dynamic models (Plant et al. 1999).

\section{LITERATURE CITED}

Allen-Diaz, B., and J. W. Bartolome. 1998. Sagebrush-grass vegetation dynamics: comparing classical and state-transition models. Ecological Applications 8:795804.

Anderson, J. E., And K. E. Holte. 1981. Vegetation development over 25 years without grazing on sagebrush-dominated rangeland in southeastern Idaho. Journal of Range Management 34:25-29.

Balley, D. W., J. E. Gross, E. A. Laca, L. R. Rittenhouse, M. B. Coughenour, D. M. Swift, AND P. L. Sims. 1996. Mechanisms that result in large herbivore grazing distribution patterns. Journal of Range Management 49:386-400.

Beers, T. W., P. E. Dress, and L. C. Wensel. 1966. Aspect transformation in site productivity research. Journal of Forestry 64:691-692.

Bestelmeyer, B. T., J. R. Brown, K. M. Havstad, R. Alexander, G. Chavez, and J. E. HerRICK. 2003. Development and use of state-and-transition models for rangelands. Journal of Range Management 56:114-126.

Bestelmeyer, B. T., A. J. Tugel, G. L. Peacock, D. G. Robinett, P. L. Shaver, J. R. Brown, J. E. Herrick, H. Sanchez, and K. M. Havstad. 2009. State-and-transition models for heterogeneous landscapes: a strategy for development and application. Rangeland Ecology \& Management 62:1-15.

Bestelmeyer, B. T., J. P. Ward, and K. M. Havstad. 2006. Soil-geomorphic heterogeneity governs patchy vegetation dynamics at an arid ecotone. Ecology 87:963-973.

Blackburn, W. H., F. B. Pierson, C. L. Hanson, T. L. Thurow, and A. L. Hanson. 1992. The spatial and temporal influence of vegetation on surface soil factors in semiarid rangelands. Transactions of the ASAE (American Society of Agricultural Engineers) 35:479-486.

BLAISDELL, J. P. 1953. Ecological effects of planned burning of sagebrush-grass range on the upper Snake River Plains. Washington, DC, USA: USDA. Technical Bulletin No. 1075.39 p.

BonHAM, C. D. 1989. Measurements for terrestrial vegetation. New York, NY, USA: Wiley-Interscience. $338 \mathrm{p}$.

Bork, E., N. West, and J. Walker. 1998. Cover components on long-term seasonal sheep grazing treatments in three-tip sagebrush steppe. Journal of Range Management 51:293-300.

Briske, D. D., S. D. Fuhlendorf, and F. E. Smeins. 2006. A unified framework for assessment and application of ecological thresholds. Rangeland Ecology \& Management 59:225-236.

BuRke, I. C., W. Reiners, and R. Olson. 1989. Topographic control of vegetation in a mountain big sagebrush steppe. Vegetatio 84:77-86.

Cagney, J., E. Bainter, B. Budd, T. Christiansen, V. Herren, M. Holloran, B. Rashford, M. Smith, AND J. WillaAms. 2010. Grazing influence, objective development, and management in Wyoming's greater sage-grouse habitat. Laramie, WY, USA: University of Wyoming Cooperative Extension Service. p. 57.

Christian, J. M., and S. D. Wilson. 1999. Long-term ecosystem impacts of an introduced grass in the northern Great Plains. Ecology 80:2397-2407.

Cingolani, A. M., I. Noy-MeIR, And S. Diaz. 2005. Grazing effects on rangeland diversity: a synthesis of contemporary models. Ecological Applications 15:757-773.

Dufrene, M., and P. Legendre. 1997. Species assemblages and indicator species: the need for a flexible asymmetrical approach. Ecological Monographs 67:345-366.

Eluson, L. 1960. Influence of grazing on plant succession of rangelands. Botanical Review 26:1-78.

Ewers, B. E., And E. Pendall. 2008. Spatial patterns in leaf area and plant functional type cover across chronosequences of sagebrush ecosystems. Plant Ecology 194:67-83.

Foran, B. D., G. BAStIN, AND K. A. Shaw. 1986. Range assessment and monitoring in arid lands-the use of classification and ordination in range survey. Journal of Environmental Management 22:67-84.
Fynn, R. W. S., And T. G. O'Connor. 2000. Effect of stocking rate and rainfall on rangeland dynamics and cattle performance in a semi-arid savanna, South Africa. Journal of Applied Ecology 37:491-507.

GLEASON, H. A. 1926. The individualistic concept of the plant association. Bulletin of the Torrey Botanical Club 53:7-26.

Huenneke, L. F., J. P. Anderson, M. Remmenga, and W. H. Schlesinger. 2002. Desertification alters patterns of aboveground net primary production in Chihuahuan ecosystems. Global Change Biology 8:247-264.

JaCKSON, R. D., AND J. W. Bartolome. 2002. A state-transition approach to understanding nonequilibrium plant community dynamics in Californian grasslands. Plant Ecology 162:49-65.

Kachergis, E., M. E. Rocca, And M. E. Fernandez-Gimenez. 2011. Indicators of ecosystem function identify alternate states in the sagebrush steppe. Ecological Applications 21:2781-2792.

KEDDY, P. 1991. Working with heterogeneity: an operator's guide to environmental gradients. In: J. Kolasa and S. T. A. Pickett (EDS.). Ecological heterogeneity. New York, NY, USA: Springer-Verlag. p. 181-201.

KNAPP, C. N. 2008. Knowledge with a place: exploring rancher knowledge of history and ecology in the Elkhead watershed in Northwest Colorado [thesis]. Fort Collins, CO, USA: Colorado State University. 396 p.

Knapp, C. N., and M. E. Fernandez-Gimenez. 2009. Understanding change: integrating rancher knowledge into state-and-transition models. Rangeland Ecology \& Management 62:510-521.

Knapp, C. N., M. E. Fernandez-Gimenez, E. Kachergis, and A. Rudeen. 2011. Using participatory workshops to integrate state-and-transition models created with local knowledge and ecological data. Rangeland Ecology \& Management 64:158-170.

KruskaL, J. B. 1964. Nonmetric multidimensional scaling: a numerical method. Psychometrika 29:115-129.

Ludwig, J. A., B. P. Wilcox, D. D. Breshears, D. J. Tongway, and A. C. Imeson. 2005. Vegetation patches and runoff-erosion as interacting ecohydrological processes in semiarid landscapes. Ecology 86:288-297.

Martin, K. L., AND L. K. KIRKMAn. 2009. Management of ecological thresholds to reestablish disturbance-maintained herbaceous wetlands of the south-eastern USA. Journal of Applied Ecology 46:906-914.

McAulfFE, J. R. 1994. Landscape evolution, soil formation, and ecological patterns and processes in Sonoran Desert bajadas. Ecological Monographs 64:111-148.

McCune, B., And J. B. Grace. 2002. Analysis of ecological communities. Gleneden Beach, OR, USA: MJM Software Design. 300 p.

Mlller, R. F., T. J. SVEJCAR, AND N. E. WeSt. 1994. Implications of livestock grazing in the intermountain sagebrush region: plant composition. In: M. Vavra, W. A. Laycock, and R. D. Pieper (EDS.). Ecological implications of livestock herbivory in the west. Denver, CO, USA: Society for Range Management. p. 101-146.

Monger, H. C., AND B. T. Bestelmeyer. 2006. The soil-geomorphic template and biotic change in arid and semi-arid ecosystems. Journal of Arid Environments 65:207218.

Oksanen, J., F. G. Blanchet, R. Kindt, P. Legendre, R. B. O'Hara, G. L. Simpson, P. Solymos, M. H. H. Stevents, and H. Wagner. 2011. Vegan: community ecology package. $\mathrm{R}$ package version 1.17-12. http://CRAN.R-project.org/package= vegan. Accessed 15 March 2011.

Oliva, G., A. Cibils, P. Borrelli, and G. Humano. 1998. Stable states in relation to grazing in Patagonia: a 10-year experimental trial. Journal of Arid Environments 40:113-131.

O'Neill, R. V., D. L. Deangelis, J. B. Waide, and T. F. H. Allen. 1986. A hierarchical concept of ecosystems. Princeton, NJ, USA: Princeton University Press. 253 p.

Passey, H. B., And V. K. Hugie. 1962. Sagebrush on relict ranges in the Snake River plains and northern Great Basin. Journal of Range Management 15:273-278.

Passey, H. B., V. K. Hugie, E. W. Willams, and D. E. Ball. 1982. Relationships between soil, plant community, and climate on rangelands of the Intermountain West. Washington, DC, USA: USDA Soil Conservation Service. Technical Bulletin 1669. $123 \mathrm{p}$

Peters, D. P. C., B. T. Bestelmeyer, J. E. Herrick, E. L. Fredrickson, H. C. Monger, and K. M. Havstad. 2006. Disentangling complex landscapes: new insights into arid and semi-arid system dynamics. Bioscience 56:491-501.

Petersen, S. L., T. K. Stringham, and B. A. Roundy. 2009. A process-based application of state-and-transition models: a case study of western juniper (Juniperus occidentalis) encroachment. Rangeland Ecology \& Management 62:186-192. 
Pierson, F. B., P. R. Robichaud, C. A. Moffet, K. E. Spaeth, S. P. Hardegree, P. E. Clark, AND C. J. WiLliams. 2008. Fire effects on rangeland hydrology and erosion in a steep sagebrush-dominated landscape. Hydrological Processes 22:2916-2929.

Plant, R. E., M. P. Vayssieres, S. E. Greco, M. R. George, and T. E. Adams. 1999. A qualitative spatial model of hardwood rangeland state-and-transition dynamics. Journal of Arid Environments 52:51-59.

Rietkerk, M., S. C. Dekker, P. C. de Ruiter, and J. van de Koppel. 2004. Self-organized patchiness and catastrophic shifts in ecosystems. Science 305:1926-1929.

Robertson, D. R., J. L. Nielsen, and N. H. Bare. 1966. Vegetation and soils of alkali sagebrush and adjacent big sagebrush ranges in North Park, Colorado. Journal of Range Management 19:17-20.

Rodriguez Iglesias, R. M., and M. M. Kothmann. 1997. Structure and causes of vegetation change in state and transition model applications. Journal of Range Management 50:399-408.

Sasaki, T., T. Okayasu, U. Jamsran, and K. Takeuchl. 2008. Threshold changes in vegetation along a grazing gradient in Mongolian rangelands. Journal of Ecology 96:145-154.

Schaetzl, R. J., and S. Anderson. 2005. Soils: genesis and geomorphology. Cambridge, UK: Cambridge University Press. 790 p.

Scheffer, M., S. R. Carpenter, J. A. Foley, C. Folke, and B. Walker. 2004. Catastrophic shifts in ecosystems. Nature 413:591-596.

Schlesinger, W. H., J. F. Reynolds, G. L. Cunningham, L. F. Huenneke, W. M. Jarrell, R. A. VIRGiniA, AND W. G. Whitford. 1990. Biological feedbacks in global desertification. Science 247:1043-1048.

Schoeneberger, P. J., D. A. Wysocki, E. C. Benham, and W. D. Broderson. 1998. Field book for describing and sampling soils. Lincoln, NE, USA: USDA-NRCS National Soil Survey Center. 228 p.

StuRGES, D. 1993. Soil-water and vegetation dynamics through 20 years after big sagebrush control. Journal of Range Management 46:161-169.

Suding, K. N., K. L. Gross, and G. R. Houseman. 2004. Alternative states and positive feedbacks in restoration ecology. Trends in Ecology and Evolution 19:46-53.

Suding, K. N., AND R. J. HobBs. 2009a. Models of ecosystem dynamics as frameworks for restoration ecology. In: R. J. Hobbs and K. N. Suding (EDS.). New models for ecosystem dynamics and restoration. Washington, DC, USA: Island Press. p. 321.
Suding, K. N., and R. J. HobBs. 2009b. Threshold models in restoration and conservation: a developing framework. Trends in Ecology \& Evolution 24:271279 .

Thllenius, J., AND G. Brown. 1974. Long-term effects of chemical control of big sagebrush. Journal of Range Management. 27:223-224.

[USDA-NRCS] US Department of Agriculture-Natural Resources Conservation Service. 2003. National range and pasture handbook. Washington, DC, USA: USDA Grazing Lands Technology Institute. 573 p.

USDA-NRCS. 2009. Web soil survey. Available at: http://www.websoilsurvey.nrcs. usda. gov. Accessed 1 August 2009.

USDA-NRCS. 2011a. Ecological site information system. Available at: http://esis.sc. egov.usda. gov/ESIS. Accessed 30 December 2011.

USDA-NRCS. 2011b. The PLANTS database. Available at: http://www.plants.usda. gov. Accessed 15 March 2011.

[USDA-SCS] US Department of Agriculture-Soll Conservation Service. 1975. Technical guide. Denver, CO, USA: USDA-Soil Conservation Service.

WEST, N. E., AND T. P. YoRKS. 2002. Vegetation responses following wildfire on grazed and ungrazed sagebrush semi-desert. Journal of Range Management 55:171181.

WEST, N. E., AND J. A. Young. 2000. Intermountain valleys and lower mountain slopes. In: M. G. Barbour and W. D. Billings (EDS.). North American terrestrial vegetation. Cambridge, UK: Cambridge University Press. p. 255-284.

Westoby, M., B. Walker, and I. Noy-MelR. 1989. Opportunistic management for rangelands not at equilibrium. Journal of Range Management 42:266-274.

WhitTAKER, R. H. 1967. Gradient analysis of vegetation. Biological Reviews of the Cambridge Philosophical Society 42:207-264.

WinwarD, A. 2004. Sagebrush of Colorado: taxonomy, distribution, ecology and management. Denver, C0, USA: Colorado Division of Wildlife. 42 p.

WISHART, D. 1969. An algorithm for hierarchical classifications. Biometrics 25:165170.

Zamora, B., and P. Tueller. 1973. Artemisia arbuscula, A. longiloba, and A. nova habitat types in northern Nevada. Western North American Naturalist 33:225242. 